\title{
Problematyka powstawania zabudowy biurowej na terenach poprzemysłowych na przykładzie koncentracii budynków biurowych przy ulicy Strzegomskiej i ulicy Muchoborskiej we Wroctawiu
}

\section{The issue of office building development in post-industrial areas based on the example of the office building concentration in Wroctaw (Poland), Strzegomska Street and Muchoborska Street}

Streszczenie: Spadek znaczenia przemysłu w drugiej połowie XX wieku na rzecz wzrostu sektora usługowego i finansowego spowodowały, że współczesna przestrzeń pracy jest nierozerwalnie związana z zabudową biurową. Biura, a często ich koncentracje w postaci dzielnic biznesowych, tworzą znaczące skupiska miejsc pracy w dużych miastach. Tematem badań jest zagadnienie tworzenia nowych przestrzeni pracy oraz zmian przestrzennych z tym związanych. Celem pracy jest analiza powstawania koncentracji budynków biurowych na terenach poprzemysłowych. Scharakteryzowana została również struktura funkcjonalno-przestrzenna nowej dzielnicy biurowej. Zagadnienie zbadano na przykładzie terenów przy ulicy Strzegomskiej i ulicy Muchoborskiej we Wrocławiu, których proces transformacji rozpoczął się w latach 90. XX wieku. Jako metodę badawczą zastosowano analizy porównawcze danych historycznych, archiwalnych i obowiązujących opracowań planistycznych oraz inwentaryzację stanu istniejącego. Charakterystyka wrocławskiej dzielnicy biurowej oraz wiedza na temat etapów jej powstawania należą do głównych rezultatów badań. Zmiana terenów przemysłowych na usługi biurowe może być jednym ze sposobów na ich rewitalizację, nadanie nowego charakteru dzielnicy oraz utrzymanie miejsc pracy na obszarze miasta.

\footnotetext{
Abstract: Changes in the industry and an increase in the meaning of services and the financial sector causes the temporary working environment to be strongly connected with offices. Therefore, office buildings and their concentrations are the main workplace in our cities. The aim of the article is to examine a business district based on the example of office building concentration in the vicinity of Strzegomska and Muchoborska Street in Wrocław (Poland). Spatial changes and the process of new urban tissue development are analysed. Functional and spatial structure of office building concentration in Wrocław is also investigated. Comparative analysis of historical data, spatial documents, and urban inventory are used as research method. Spatial identification and knowledge about office building concentration development are the main results. The conversion of post-industrial area into business district could be a solution to urban revitalisation and creation of a new city space.
} 
Słowa kluczowe: budynki biurowe, dzielnica biznesowa, ulica Muchoborska, ulica Strzegomska, Wrocław Keywords: business district, office buildings, Muchoborska Street, Strzegomska Street, Wrocław (Poland)

Otrzymano: 13 marca 2020

Received: 13 March 2020

Zaakceptowano: 31 stycznia 2021

Accepted: 31 January 2021

\section{Sugerowana cytacja / Suggested citation:}

Kierzkowska, A. (2021). Problematyka powstawania zabudowy biurowej na terenach poprzemysłowych na przykładzie koncentracji budynków biurowych przy ulicy Strzegomskiej i ulicy Muchoborskiej we Wrocławiu. Prace Komisji Geografii Przemysłu Polskiego Towarzystwa Geograficznego, 35(1), 56-71, doi: $10.24917 / 20801653.351 .4$

\section{WSTĘP}

Dzielnice biznesowe występują w większości dużych miast na całym świecie. Jednak w artykule zostanie opisana charakterystyka takich struktur urbanistycznych tylko w Europie. Pod koniec XX wieku w wielu największych miastach europejskich zaczęły powstawać dzielnice biznesowe, będące koncentracjami budynków biurowych. Pierwsze z nich pojawiły się już w latach 80 . XX wieku w miastach o największym znaczeniu gospodarczym, takich jak Londyn, Paryż, Wiedeń czy Amsterdam. Geneza powstawania dzielnic biznesowych jest ściśle związana z procesem globalizacji i spadkiem znaczenia przemysłu na korzyść wzrostu sektora usługowego i finansowego (Aranya, 2003; Sassen, 2006b). W drugiej połowie XX wieku nastąpił proces rozłączania produkcji od sektora zarządzającego (Sassen, 2006). Zakłady przemysłowe w wielu przypadkach zostały przeniesione z krajów rozwiniętych do krajów rozwijających się, gdzie koszty produkcji były znaczenie tańsze. Natomiast działy zarządzania były lokowane w miastach wysoko usytuowanych w światowej hierarchii miast, które stały się „centrami zarządzania" globalną gospodarką (Derudder, Witlox, 2008). Jednak nowa organizacja firm, wymagała również nowej przestrzeni pracy (Sassen, 2001). Tak powstało zapotrzebowanie na nowe powierzchnie biurowe. Konsekwentnie zaczęły powstawać koncentracje budynków biurowych, skupiające wiele różnych przedsiębiorstw - często nawet ze sobą konkurujących. Takie dzielnice biznesowe są skierowane głównie do dużych międzynarodowych firm. Na ich terenie znajduje się szereg udogodnień, które zapewnia takie skupisko (Ketels, 2011; Porter, 1998).

Można wyróżnić różne rodzaje koncentracji biurowych. Podział wynika przede wszystkim z lokalizacji takich skupisk na obszarze miasta. Zgodnie z klasyfikacją zaproponowaną przez Halla jest to Centrum A, B i C (Hall, 2014). Centrum A to najlepsza lokalizacja, położona w ścisłym centrum miasta. Wybierają ją firmy, którym zależy na prestiżowym adresie, bliskości podobnych firm i dobrej dostępności komunikacji zbiorowej (Hall, 2014). Centrum B jest położone na obrzeżach śródmieścia. Jest to ciągle atrakcyjna lokalizacja pod względem dostępności komunikacją zbiorową. Jednak łatwiejszy jest również dojazd transportem samochodowym. Najczęściej uwarunkowania terenów inwestycyjnych są bardziej dogodne a ich ceny przystępniejsze niż w ścisłym centrum miasta. Centra C to miejsca pracy zlokalizowane na obrzeżach miasta. Wymagają małej liczby pracowników przy jednocześnie dużej powierzchni zabudowy oraz zapewnionej dobrej dostępności do sieci transportu drogowego. Przykładami takich miejsc pracy są centra logistyczne. 
W artykule zostanie omówiona koncentracja budynków biurowych zlokalizowana w Centrum B, czyli na obrzeżach śródmieścia. Co ciekawe, na takich terenach najczęściej nowe inwestycje biurowe nie stanowią pierwotnej zabudowy. Powstają w wyniku likwidacji innej formy zagospodarowania. Często są to budynki przemysłowe, które zostały wzniesione w XIX wieku. Już w drugiej połowie XX wieku, w wyniku zmian gospodarczych, ich znaczenie spadło a obszar został wykorzystany w innej funkcji. Co znaczące, władze miast często pozostawiają wiodące przeznaczenie terenów, którym jest miejsce pracy. Zmienia się tylko forma jej wykonywania, a co jest z tym związane - forma zabudowy. W wyniku takich przekształceń w europejskich miastach powstało wiele dzielnic biznesowych. Najbardziej wielkoskalowym przedsięwzięciem jest z pewnością Canary Wharf w Londynie w Wielkiej Brytanii (Hall, Tewdwr-Jones, 2011). Podobną genezę powstania ma również warszawski Służewiec Przemysłowy (Chmielewski, Kotaszewicz, Mieszkowski, 2004), który stanowi jedną z największych koncentracji miejsc pracy w stolicy Polski. Ciekawym przykładem, nadal w trakcie realizacji, jest koncentracja budynków biurowych położona wzdłuż ulicy Strzegomskiej i ulicy Muchoborskiej we Wrocławiu. Ze względu na wielkość i znaczenie Wrocławia, jest to dzielnica biznesowa o znaczenie mniejszej skali i dynamice rozwoju niż przytoczone przykłady z Londynu i Warszawy. Dzięki wciąż trwającemu procesowi kształtowania, można obserwować poszczególne etapy jej powstawania oraz zachodzące przemiany z funkcji przemysłowej na biurową.

Celem artykułu jest analiza powstawania koncentracji budynków biurowych na terenach poprzemysłowych i ich analiza funkcjonalno-przestrzenna. Zagadnienie zostanie omówione na przykładzie budynków biurowych zlokalizowanych wzdłuż ulicy Strzegomskiej i ulicy Muchoborskiej we Wrocławiu (fotografie 1, 2). Badany teren

Fotografia 1. Zabudowa biurowa przy ul. Strzegomskiej we Wrocławiu

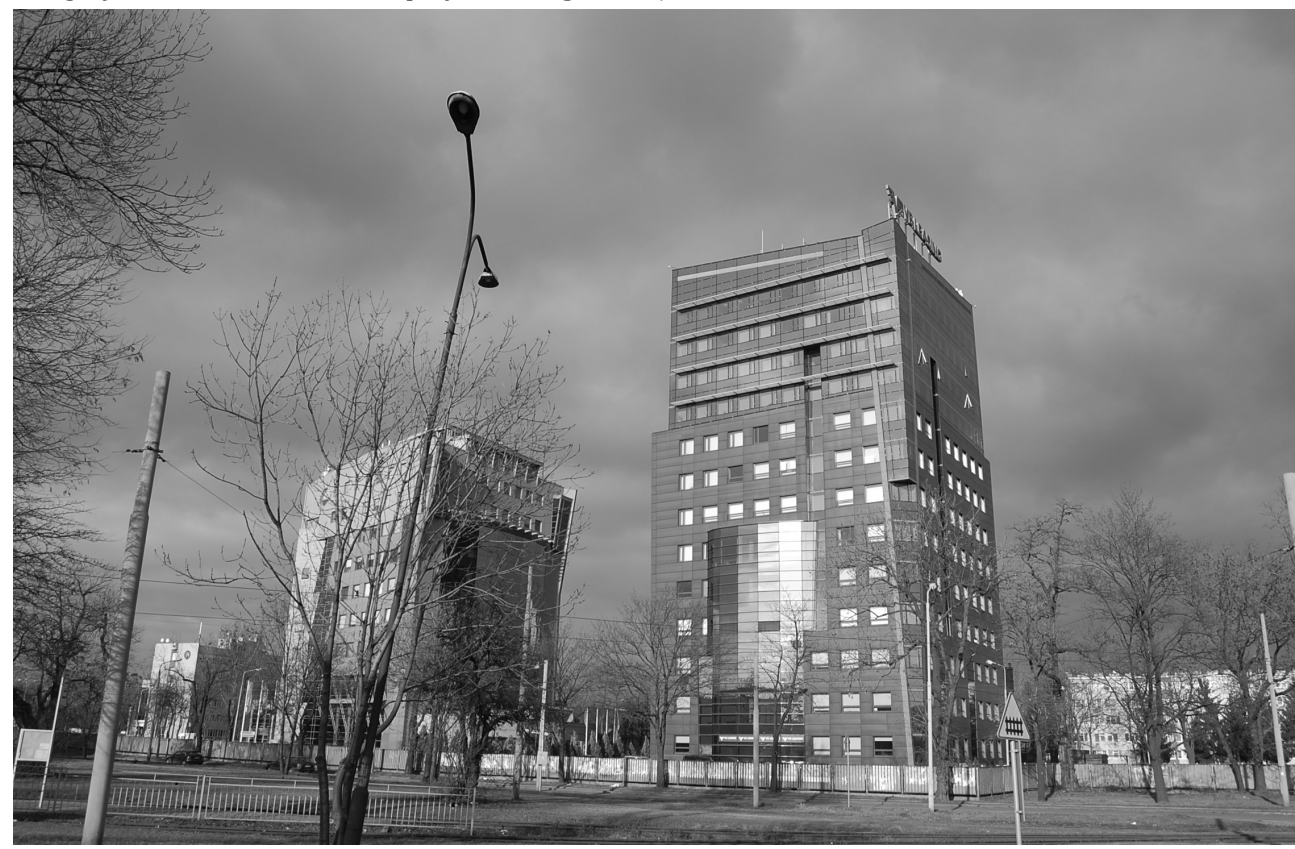

Źródło: zdjęcie własne 
Fotografia 2. Zabudowa biurowa przy ul. Duńskiej we Wrocławiu

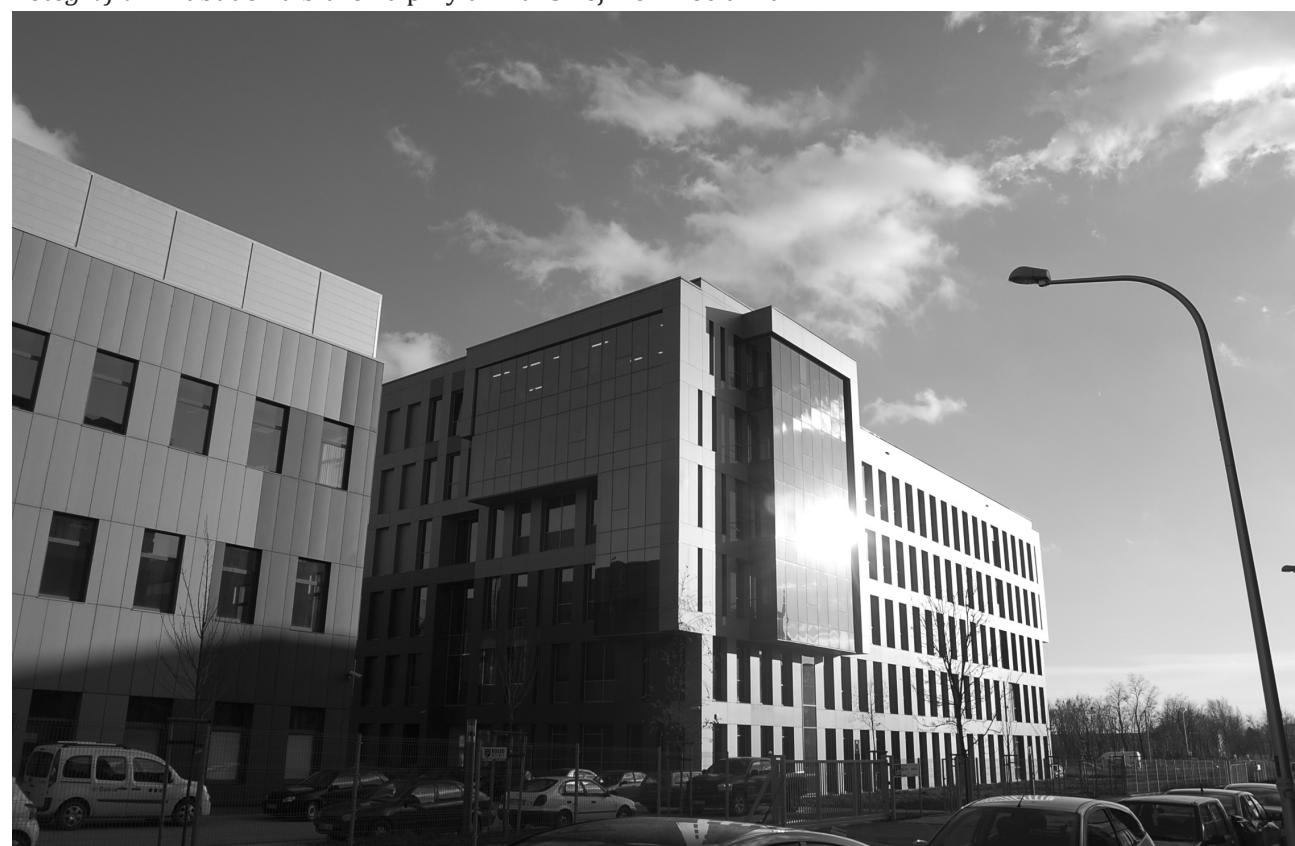

Źródło: zdjęcie własne

położony jest na zachód od centrum miasta, w dzielnicy Fabryczna, osiedle Muchobór Mały. Granicę badanej koncentracji budynków biurowych wyznacza od wschodu plac Strzegomski, południa - ulica Fabryczna i ulica Szwajcarska, zachodu - ulica Klecińska, a północy - linia kolejowa. Powierzchnia badanego terenu wynosi 71,7 ha, na którym znajduje się 381 budynków biurowych.

\section{PRZEGLĄD LITERATURY}

Badania dotyczące omawianej problematyki przedstawiono w dwóch nurtach badawczych. Pierwszy dotyczy zagadnienia powstawania i funkcjonowania dużych skupisk zabudowy biurowej. Druga grupa badań jest związana z przekształcaniem terenów poprzemysłowych.

Przyczyny powstawania i uwarunkowania lokalizacyjne dla zabudowy biurowej tworzą obszerną grupę badań. Są one związane z typowaniem światowych hierarchii miast w oparciu o uwarunkowania globalnej gospodarki. Wielu badaczy (Friedmann, 2006; Hall, 1997; Sassen, 2001) udowadnia, że tylko w miastach usytuowanych wystarczająco wysoko w tej hierarchii lokuje się międzynarodowy kapitał, którego fizyczną przestrzenią są budynki biurowe. Marcuse opisuje to zjawisko jako lokalizację globalnego kapitału w lokalnej przestrzeni (Marcuse, 2008). W badaniach naukowych najczęściej opisywane są negatywne skutki powstawania tak dużych skupisk zabudowy biurowej, z czego najczęściej są wymieniane monofunkcyjność, brak powiązań z innymi częściami miasta czy uwzględniania lokalnych uwarunkowań (Majoor, 2009; Marcuse,

${ }^{1}$ Dane na podstawie inwentaryzacji z 2014 roku. 
2008). Marcuse takie struktury urbanistyczne zdefiniował jako cytadele (Marcuse, 2008). Natomiast Majoor, na przykładzie trzech europejskich dzielnic w Amsterdamie, Kopenhadze i Barcelonie, opisuje koncentracje budynków biurowych jako „megaprojekty". Są one niepołączonymi z otoczeniem strukturami przestrzennymi, będącymi efektem globalnej ekonomii i kultury (Majoor, 2009). Takie dzielnice biurowe są „zamknięte" pod względem przestrzennym i nastawione głównie na potrzeby inwestorów (Majoor, 2009). Jak podkreśla Majoor, nie są one zgodne z ideą nowej urbanistyki, według której powstają. Fundamentem nowej urbanistyki dla dzielnic biznesowych jest tworzenie przestrzeni miejskich o intensywnej i zróżnicowanej zabudowie, będących połączeniem miejsca pracy, zamieszkania oraz usług (Majoor, 2009). Według badań Swyngedouwa, Moulaerta i Rodriguez dzielnice biurowe kwalifikuje się również jako wielkoskalowe projekty rozwoju. Są one sposobem na rewitalizację wybranych części miasta dzięki lokalizacji odpowiednich aktywności. Takie projekty są również metodą wzmocnienie pozycji ekonomicznej miasta, a nawet regionu poprzez tworzenie nowych miejsc pracy (Swyngedouw, Moulaert, Rodriguez, 2002). Autorzy zauważają, że omawiane inwestycje realizuje się zgodnie z międzynarodowymi strategiami w oderwaniu od lokalnego kontekstu. Powstają według innych uwarunkowań - mają inną skalę zabudowy, krótki czas wznoszenia, większą swobodę inwestycji oraz silne kryterium efektywności (Swyngedouw, Moulaert, Rodriguez, 2002). Pogłębia to różnice pomiędzy dzielnicami biurowymi a pozostałymi częściami miasta. W badaniach naukowych koncentracje budynków biurowych najczęściej są opisywane jako katalizatory rozwoju gospodarczego, silnie związane $\mathrm{z}$ organizacją globalnej gospodarki. Natomiast pod względem przestrzennym najczęściej nie nawiązują do lokalnych uwarunkowań.

Istotne dla problematyki poruszanej $\mathrm{w}$ artykule są również badania naukowe dotyczące przekształceń terenów poprzemysłowych. Badacze omawiają różne aspekty tego procesu. Sikorski analizuje przeobrażenia terenów przemysłowych na obszarze miasta Wrocławia. Autor wskazuje, że proces ten był możliwy po 1989 roku. Jednocześnie zwraca uwagę, że jest to zagadnienie przemian morfologicznych miasta opisanych przez Conzena w 1960 roku. Tereny przemysłowe przeszły pięć faz rozwoju: inicjacji, wypełnienia, kulminacji, recesji i stagnacji (Sikorski, 2012). Ostatnie dwa etapy spowodowały zmiany ich funkcji. Autor zwraca uwagę, że $60 \%$ terenów przemysłowych we Wrocławiu po 1989 roku uległo przekształceniu na inną formę zagospodarowania. Natomiast przeobrażenia terenów poprzemysłowych przebiegały w sposób gwałtowny i często nieskoordynowany z polityką przestrzenną prowadzoną przez władze miasta. Inny aspekt przekształcania terenów poprzemysłowych w swoich badaniach poruszają Sitek i Szajnowska-Wysocka. Problematyka kształtowania krajobrazu miejskiego powinna być realizowana również podczas procesu rewitalizacji terenów poprzemysłowych. Badacze podkreślają, że rewitalizacja ma głównie na celu rozwiązanie lub poprawę problemów społecznych. Jednak aspekt poprawy jakości przestrzeni miejskiej jest również istotny (Sitek, Szajnowska-Wysocka, 2018). Rewitalizacja terenów poprzemysłowych powinna być wykorzystywana do poprawy wizerunku części lub nawet całego miasta. Priorytetem musi być aktywizacja rewitalizowanego obszaru i wyprowadzenie nowej funkcji służącej mieszkańcom danego miasta. Tereny poprzemysłowe często posiadają zabudowę historyczną, która jest objęta ochroną. Problematykę takich przekształceń opisuje Kazimierczak i Kosmowski. Jako przykład wskazują rewitalizację terenów poprzemysłowych w Łodzi. Badacze zwracają uwagę na problemy formalne rewitalizacji takich terenów. Konflikt często występuje pomiędzy interesami prywatnych 
inwestorów a władzami miasta. Niestety uwarunkowania w postkomunistycznych krajach, do jakich należy Polska, nie sprzyjają ochronie i rewitalizacji terenów poprzemysłowych o wysokich wartościach zabudowy (Kazimierczak, Kosmowski, 2018). Jest to niewątpliwie niekorzystne zjawisko. Zagadnienie przekształcania terenów poprzemysłowych jest analizowane w różnych aspektach. Badacze najczęściej zwracają uwagę na kierunki takiego procesu, stawiane wymagania oraz problemy z tym związane.

\section{METODA BADAWCZA}

W celu odpowiedzenia na postawiony problem badawczy i przeprowadzenia niezbędnych analiz, zastosowano dwie metody badawcze. Pierwsza dotyczyła analizy historycznej badanego terenu, a dokładnie zmian przestrzennych, jakie zachodziły w tej części Wrocławia oraz dokumentów planistycznych, które te zmiany regulowały. Druga część analiz objęła strukturę funkcjonalno-przestrzenną koncentracji budynków biurowych przy ulicy Strzegomskiej i ulicy Muchoborskiej.

Materiałami źródłowymi do analizy historycznej były głównie archiwalne mapy zagospodarowania Wrocławia (Okólska i in., 1999) oraz ortofotomapy (System Informacji Przestrzennej..., 2014). Rozwój przestrzenny prześledzono na podstawie historycznych oraz już nieobowiązujących dokumentów planistycznych dla tego fragmentu oraz całego miasta (Przyłęcka, 2007). Były to głównie plany zagospodarowania przestrzennego i plany ogólne dla Wrocławia, w tym miejscowe plany zagospodarowania przestrzennego oraz studia uwarunkowań i kierunków zagospodarowania przestrzennego. Wykonano również analizę datowania terenów zabudowanych, zgodnie z okresem powstania istniejącej na nich zabudowy według stanu na 2014 rok. Źródłem informacji były archiwalne mapy miasta (Okólska i in., 1999; System Informacji Przestrzennej..., 2014). Badanie objęło koncentracje budynków biurowych przy ulicy Strzegomskiej i ulicy Muchoborskiej oraz tereny do niej przyległe. Granica tych drugich została wyznaczona w odległości około $1 \mathrm{~km}$ od granicy omawianej dzielnicy biznesowej. Porównanie koncentracji z przyległymi do niej terenami miało na celu jej charakterystykę w odniesieniu do danej części miasta. Dopiero porównanie uzyskanych wyników pozwala je zinterpretować. Wszystkie zabudowane działki zostały podzielone na cztery grupy, zgodnie z datowaniem znajdujących się na nich budynków. Pierwsza grupa to zabudowa historyczna powstała do 1945 roku. Druga to już zabudowa powojenna z lat 1946-2000. Trzeci przedział to zabudowa współczesna powstała po 2001 roku. Jest to okres największego rozwoju badanej koncentracji budynków biurowych, który trwał do około 2012 roku. Natomiast budynki zbudowane po 2012 roku, to już kolejny etap rozwoju dzielnicy. Są to inwestycje, które mogły powstać w konsekwencji już istniejącej zabudowy biurowej.

Kolejna analiza dotyczyła struktury funkcjonalno-przestrzennej koncentracji budynków biurowych przy ulicy Strzegomskiej i ulicy Muchoborskiej. Jej pierwsza część, podobnie jak analiza historyczna, objęła również tereny przyległe do badanej dzielnicy biznesowej. Wszystkie tereny zostały zinwentaryzowane w 2014 roku pod względem funkcji, jakie pełnią. Do tego celu wykonano badania terenowe oraz wykorzystano systemy informacji przestrzennej (System Informacji Przestrzennej..., 2014). Wyniki uzyskane dla obszaru koncentracji zostały porównane z tymi dla terenów przyległych. Umożliwiło to uzyskanie kontekstu miejsca i porównanie go z najbliższym otoczeniem. Bardziej szczegółowe analizy funkcjonalne wykonano tylko dla terenów koncentracji 
budynków biurowych. Zmienną była powierzchnia całkowita zabudowy, dzięki której scharakteryzowano strukturę funkcjonalną wrocławskiej dzielnicy biznesowej. Sprawdzono również, jaka jest proporcja pomiędzy zabudową biurową a innymi formami zagospodarowania terenu. Wyniki wskazały, ile powierzchni całkowitej zabudowy innej niż biurowa przypada na $100 \mathrm{~m}^{2}$ biur. Uzyskane rezultaty pozwoliły scharakteryzować strukturę funkcjonalno-przestrzenną tej części Wrocławia.

\section{ANALIZA HISTORYCZNA}

Praktycznie do XIX wieku tereny przy dzisiejszej ulicy Strzegomskiej i ulicy Muchobroskiej we Wrocławiu były w użytkowaniu rolniczym (Okólska i in., 1999). Ich atrakcyjność jako obszarów inwestycyjnych wzrosła w wyniku budowy linii kolejowej relacji Wrocław-Legnica oraz dworca kolejowego Dworzec Świebodzki w 1844 roku. Spośród różnych form zagospodarowania wybór padł na rozwój przemysłu. Jako pierwsze powstały w latach 1871-1890 zakłady produkcyjne Linke-Hoffmann Werke (Malczewski, Morelowski, Ptaszycka, 1956). Kolejnym przełomowym wydarzeniem w historii rozwoju badanych terenów było przyłączenie ich w 1928 roku do obszarów ówczesnego Wrocławia (Okólska i in., 1999). Zapoczątkowany kierunek rozwoju tych terenów pod koniec XIX wieku był również kontynuowany po zakończeniu II wojny światowej. W pierwszym polskim powojennym planie ogólnym rozwoju przestrzennego Wrocławia, analizowane tereny zostały przeznaczone pod zabudowę przemysłową (Przyłęcka, 2007). Do lat 90. XX wieku powstało kilka planów rozwoju przestrzennego Wrocławia, a w każdym z nich analizowane tereny były przeznaczone pod zabudowę przemysłową i magazynową (Przyłęcka, 2007).

Kolejny przełomowy moment w rozwoju terenów przy ulicy Strzegomskiej i ulicy Muchoborskiej nastąpił w latach 90. XX wieku. Po 1989 roku znaczenie przemysłu spadło, pojawiły się nowe uwarunkowania do lokalizowania i budowy obiektów produkcyjnych oraz magazynowych. Ich dotychczasowa lokalizacja nie spełniała nowych wymagań i nie była już tak atrakcyjna. Była to ogólna tendencja, która wystąpiła na obszarze całej Europy. Zakłady produkcyjne w wielu przypadkach zostały przeniesione do krajów rozwijających się, gdzie koszty produkcji były niższe. Bardzo wyraźna jest również tendencja do suburbanizacji przemysłu w miastach europejskich (Barski, Zathey, 2018). Dotychczasowe lokalizacje nie są już odpowiednie, a tereny inwestycyjne pod miastami spełniają nowe wymagania wielkoskalowych zakładów produkcyjnych. Obowiązujące trendy zostały zauważone również przez władze Wrocławia, które od lat 90. XX wieku zmieniły wiodące przeznaczenie terenów wzdłuż ulicy Strzegomskiej i ulicy Muchoborskiej z przemysłu i magazynów na usługi i aktywność gospodarczą. Chociaż na terenach aktywności gospodarczej możliwa jest działalność produkcyjna, ma ona już zupełnie inny charakter niż dotychczas. Są to najczęściej parki przemysłowe lub parki technologiczne, których działalność bazuje na nowych technologiach. Jednak ściśle na terenach objętych analizą dominuje zabudowa usługowa. Władze Wrocławia utrzymały w tej części miasta zagospodarowanie związane z miejscem pracy. Jednak forma prowadzonej działalności i zagospodarowania terenów jest już zupełnie inna. Dostosowana do współczesnej gospodarki.

Od początku lat 90. XX wieku dla Wrocławia powstały cztery studia uwarunkowań i kierunków zagospodarowania przestrzennego: w latach 1998, 2006, 2010 i 2018. W każdym z nich badane tereny wraz z ich niedalekim otoczeniem były 
przeznaczone jako tereny aktywności gospodarczej. W Studium z 2018 roku oś wzdłuż ulicy Strzegomskiej została wyodrębniona jako pas zabudowy usługowej. Co ciekawe, w Studium z 2010 roku na badanym obszarze wyznaczono Biegun nauki i innowacji (Studium uwarunkowań, 2010), czyli ukierunkowanie na rozwój instytutów naukowych oraz ośrodków badawczych. Taki zapis umożliwił powstanie Wrocławskiego Parku Technologicznego czy Wrocławskiego Parku Przemysłowego. Badany obszar w całości jest pokryty kilkoma miejscowymi planami zagospodarowania przestrzennego. W każdym dokumencie analizowane tereny są przeznaczane pod usługi lub aktywność gospodarczą połączoną z usługami. Takie zapisy umożliwiają powstawanie budynków biurowych.

Analiza historyczna terenów zabudowanych pozwoliła również zidentyfikować, jak rozwijała się przestrzennie badana część Wrocławia. Tereny przyległe do koncentracji budynków biurowych to głównie zabudowa mieszkaniowa wielorodzinna i usługowa, która powstała w latach 1946-2000. Jest to ponad połowa terenów zabudowanych, czyli 62,3\% (313 ha). Wynika to z faktu, że ta część miasta została w znacznym stopniu zniszczona w trakcie II wojny światowej i odbudowana po 1945 roku. Zabudowa historyczna to pojedyncze obiekty - głównie przemysłowe i magazynowe, których suma terenów wynosi 28,4\% (143 ha). Tereny zabudowane po 2001 roku to głównie uzupełnienie już istniejącej tkanki urbanistycznej miasta, które stanowią 9\% (45ha) terenów przyległych. Natomiast najnowsze budynki z lat 2012-2015 to zaledwie 0,3\% (1,7 ha).

Struktura historyczna terenów zabudowanych na obszarze badanej koncentracji budynków biurowych wzdłuż ulicy Strzegomskiej i Muchoborskiej we Wrocławiu jest zupełnie inna niż na terenach przyległych. Pomimo że nie jest to nowa część miasta, tworzy ją głównie nowa struktura urbanistyczna. Dominuje zabudowa powstała w latach 2001-2012 - 65\% (25,7 ha), czyli z największego rozwoju tej koncentracji budynków biurowych. W latach 2012-2015 zbudowano tylko dwie inwestycje, które

Rycina 1. Datowanie zabudowy na terenach przy ul. Strzegomskiej i ul. Muchoborskiej we Wrocławiu oraz na terenach do nich przyległych

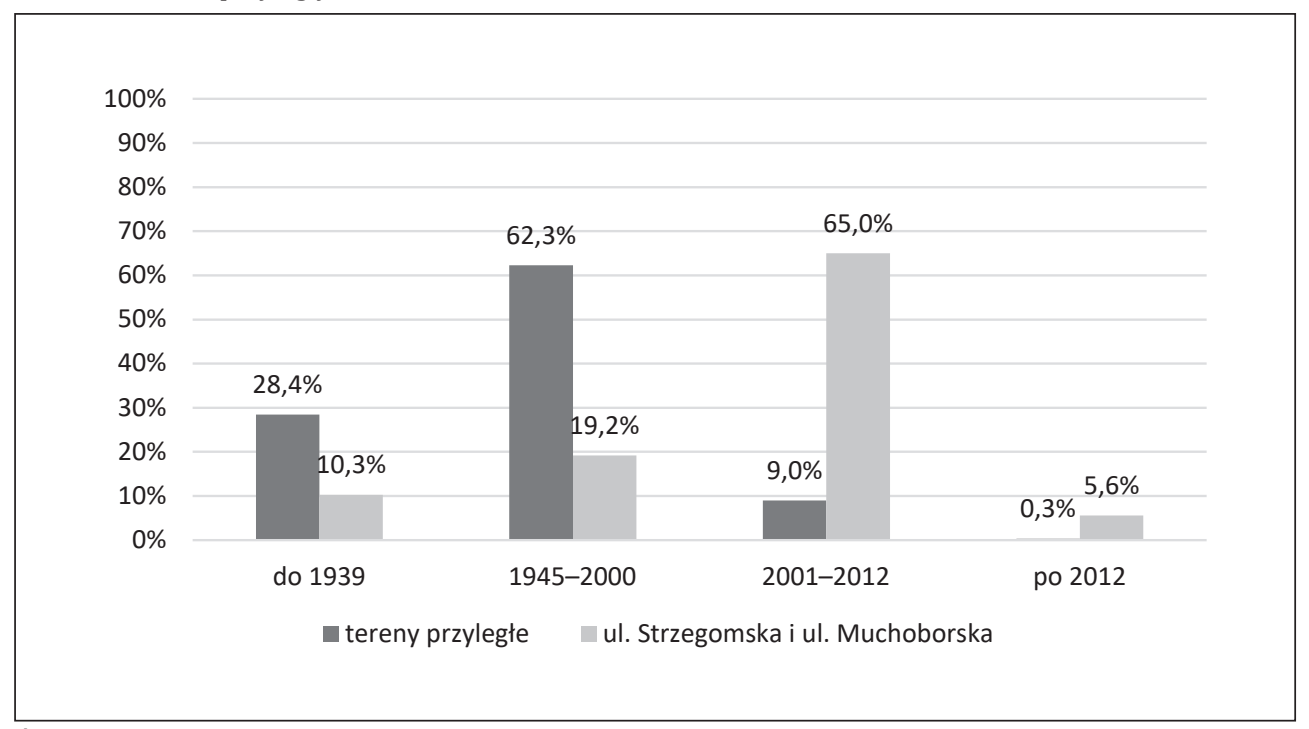

Źródło: opracowanie własne 
Rycina 2. Datowanie zabudowy na terenach przy ul. Strzegomskiej i ul. Muchoborskiej we Wrocławiu oraz na terenach do nich przyległych

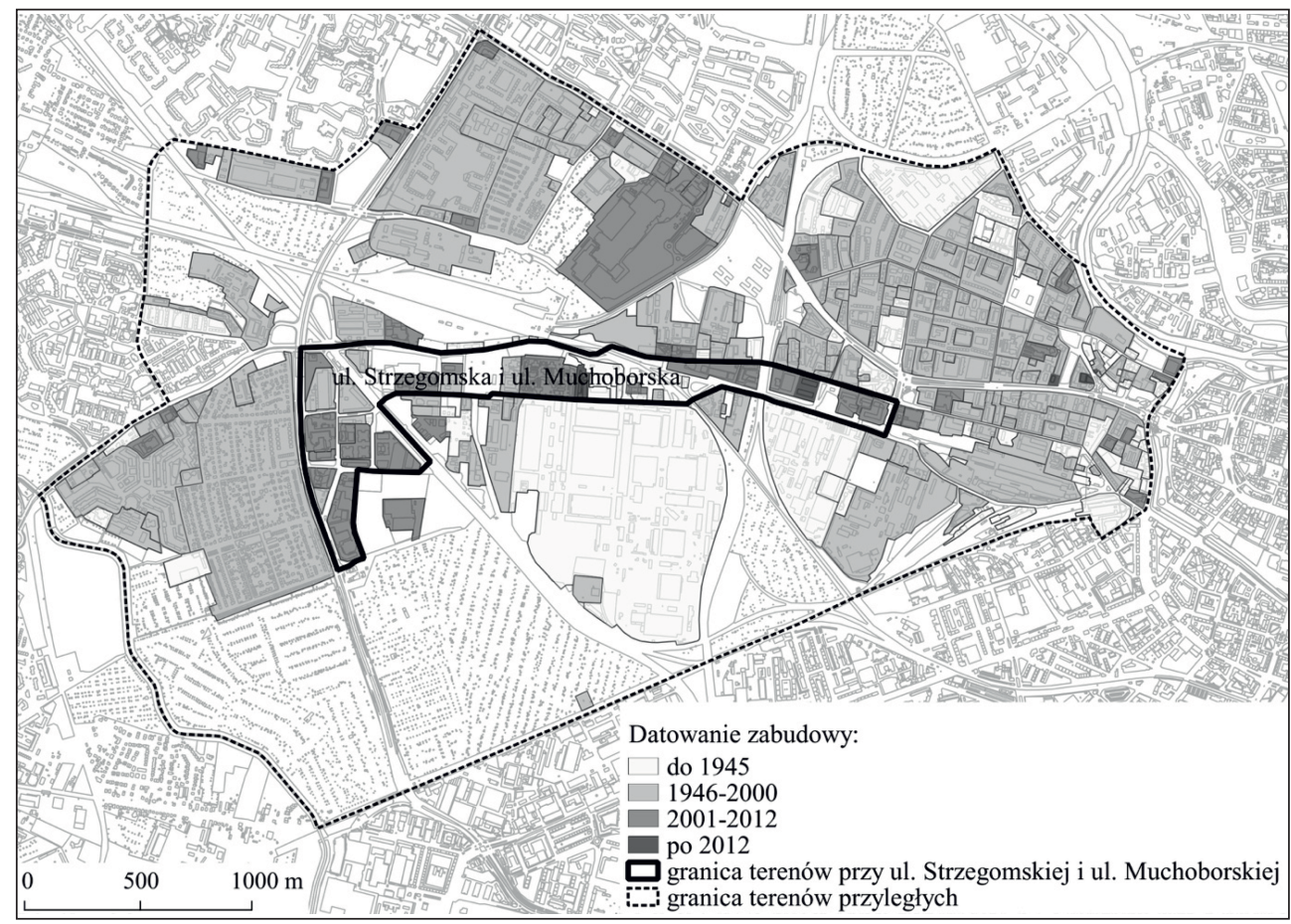

Źródło: opracowanie własne

zajmują 5,6\% (2,2 ha). Natomiast tereny zabudowane przed 1945 rokiem to $10,2 \%$ (4 ha), które obecnie pełnią funkcję usług szkolnictwa wyższego. Zabudowa z lat 1946-2000 to głównie tereny aktywności gospodarczej, które stanowią 19,2\% (7,6 ha).

\section{STRUKTURA FUNKCJONALNO-PRZESTRZENNA}

Analiza terenów koncentracji budynków biurowych przy ulicy Strzegomskiej i ulicy Muchoborskiej we Wrocławiu oraz terenów do nich przyległych objęła trzy grupy form zagospodarowania: ogólnomiejskie, związane z miejscem zamieszkania i miejscem pracy. Na terenach przyległych podział ten jest dość charakterystyczny. Połowę, czyli $53,4 \%$ (429 ha), stanowią tereny związane z miejscem zamieszkania. Badanie koncentracji budynków biurowych wykazało, że w sąsiedztwie przeważa zabudowa mieszkaniowa oraz inne formy zagospodarowania z nią związane. Zbliżony udział procentowy ma grupa zabudowy o charakterze ogólnomiejskim - 21,4\% (172 ha) i związana z miejscem pracy - 25,2\% (202 ha). Natomiast na terenach koncentracji budynków biurowych przy ulicy Strzegomskiej i ulicy Muchoborskiej dominują dwie grupy form zagospodarowania terenów. Podobne powierzchnie zajmują tereny związane z miejscem pracy 48,86\% (25,5 ha) oraz o charakterze ogólnomiejskim 49,05\% (25,6 ha). Wysoki udział procentowy drugiej grupy wynika z obecności dużych powierzchni terenów niezagospodarowanych lub zieleni nieurządzonej oraz usług nauki i szkolnictwa. 
Rycina 3. Podział na grupy form zagospodarowania terenu przy ul. Strzegomskiej i ul. Muchoborskiej oraz terenów przyległych we Wrocławiu

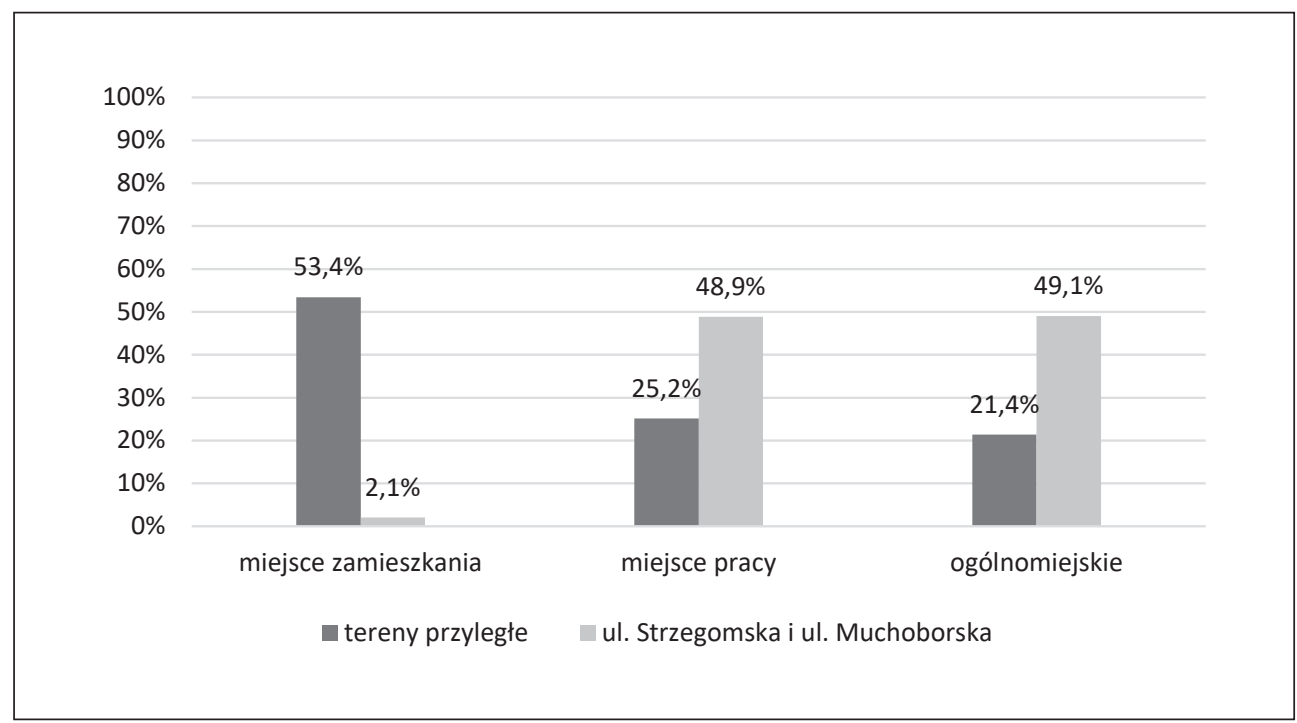

Źródło: opracowanie własne

Rycina 4. Rozmieszczenie grup form zagospodarowania terenu przy ul. Strzegomskiej i ul. Muchoborskiej oraz terenów przyległych we Wrocławiu

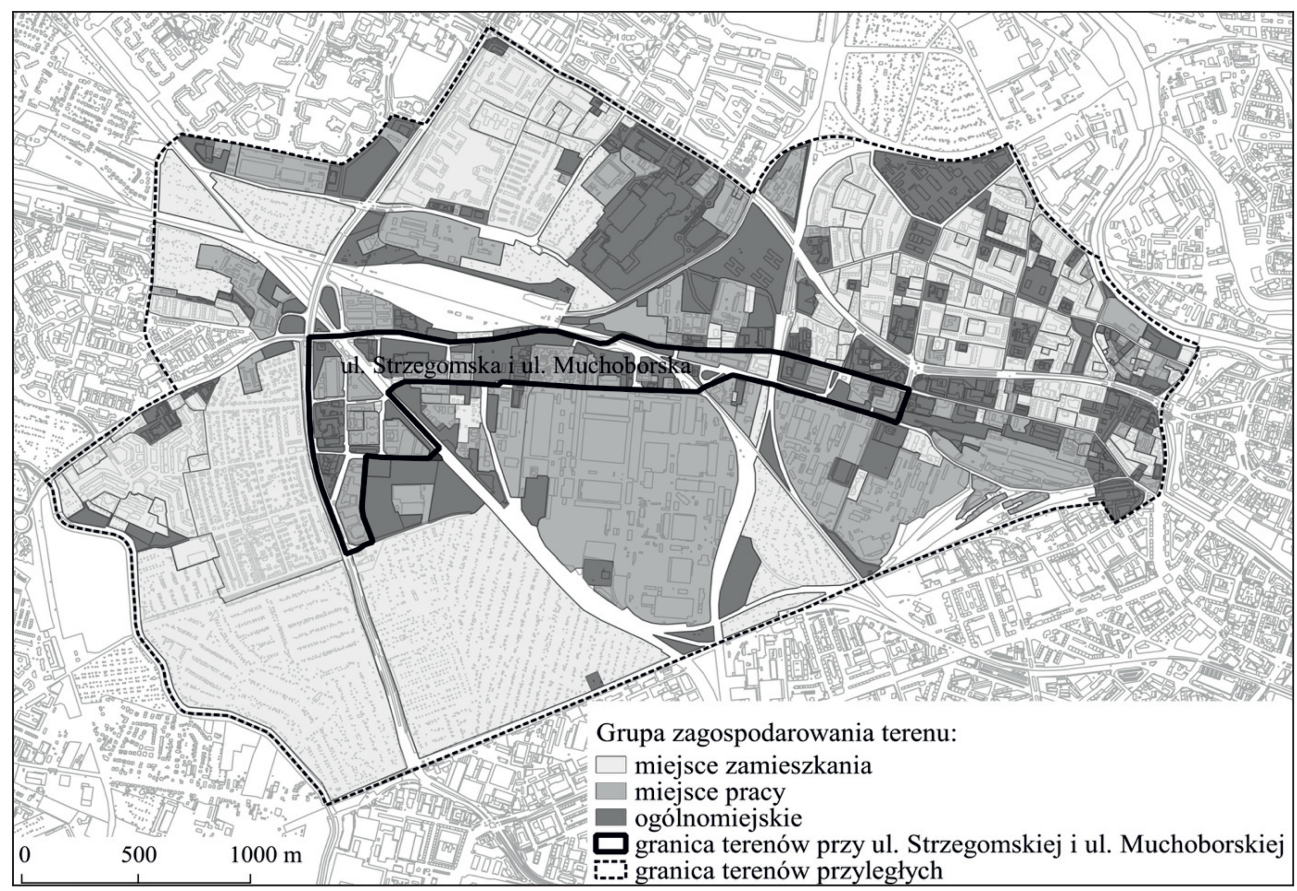

Źródło: opracowanie własne 
Szczegółowa analiza funkcjonalno-przestrzenna objęła tereny tylko koncentracji budynków biurowych przy ulicy Strzegomskiej i ulicy Muchoborskiej we Wrocławiu. Powierzchnia całkowita budynków biurowych stanowi zdecydowaną większość - 72,6\%. Zabudowa biurowa jest położona głównie przy ulicy Strzegomskiej, Robotniczej i Muchoborskiej oraz Klecińskiej. Niektóre obiekty tworzą zwarte kompleksy, takie jak Wrocławski Park Biznesu, budynki firmy IBM czy Wrocławski Park Technologiczny. Pozostałe biurowce to raczej pojedyncze inwestycje. Zabudowę biurową przeplatają inne formy zagospodarowania terenu. Jest to głównie zabudowa przemysłowa i magazynowa, najczęściej definiowana jako aktywności gospodarcze. Suma jej powierzchni całkowitej zabudowy stanowi 12\% wszystkich budynków. Duży udział zabudowy przemysłowej i magazynowej prawdopodobnie wynika z dwóch faktów. Może świadczyć o poprzednim charakterze tej części Wrocławia, która była dzielnicą przemysłową. Badana koncentracja budynków biurowych jest w trakcie powstawania, a ta część terenów nie została jeszcze przekształcona. Drugi scenariusz może być związany z przeznaczeniem tych terenów na aktywności gospodarcze i usługi. Takie zapisy w dokumentach planistycznych umożliwią powstawanie lub utrzymanie istniejącej zabudowy przemysłowej i magazynowej. Zróżnicowanie miejsc pracy wydaje się dobrym rozwiązaniem i urozmaiceniem struktury przestrzennej. Kolejną pod względem wielkości powierzchni całkowitej zabudowy są usługi, które stanowią 9,9\%. Tworzą je głównie obiekty szkolnictwa wyższego. Na terenie badanej koncentracji znajdują się również budynki zabudowy mieszkaniowej wielorodzinnej, które tworzą 5,3\% całej powierzchni całkowitej zabudowy. Atrakcyjność lokalizacji w skali miasta oraz bliskość potencjalnych miejsc pracy sprawia, że w sąsiedztwie budynków biurowych zaczyna powstawać zabudowa mieszkaniowa. Jednak zgodnie z zapisami obowiązujących na tym obszarze dokumentów planistycznych, żadna zabudowa mieszkaniowa nie została tutaj dopuszczona. Zaplanowano wyłącznie przestrzeń pracy. Zabudowę mieszkaniową przewidziano na terenach graniczących z badaną dzielnicą biznesową.

Rycina 5. Podział powierzchni całkowitej zabudowy na terenach przy ulicy Strzegomskiej i ulicy Muchoborskiej we Wrocławiu

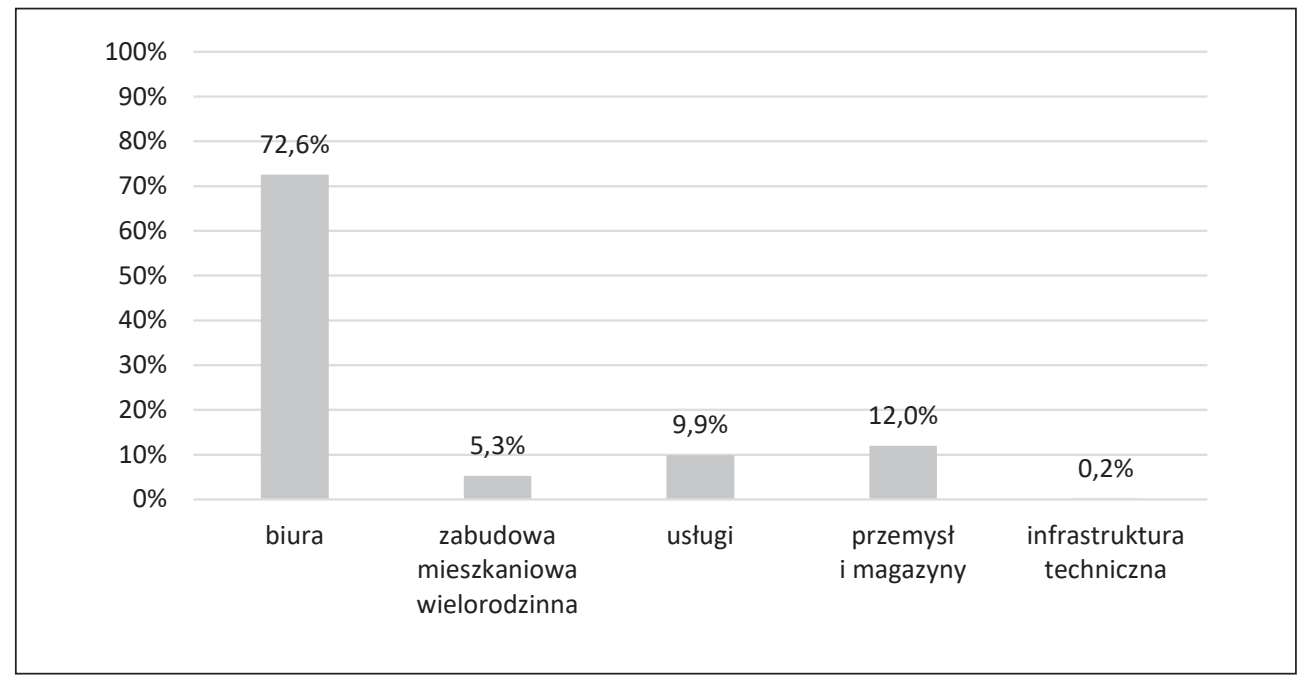

Źródło: opracowanie własne 
Rycina 6. Funkcje zabudowy na terenach przy ulicy Strzegomskiej i ulicy Muchoborskiej we Wrocławiu

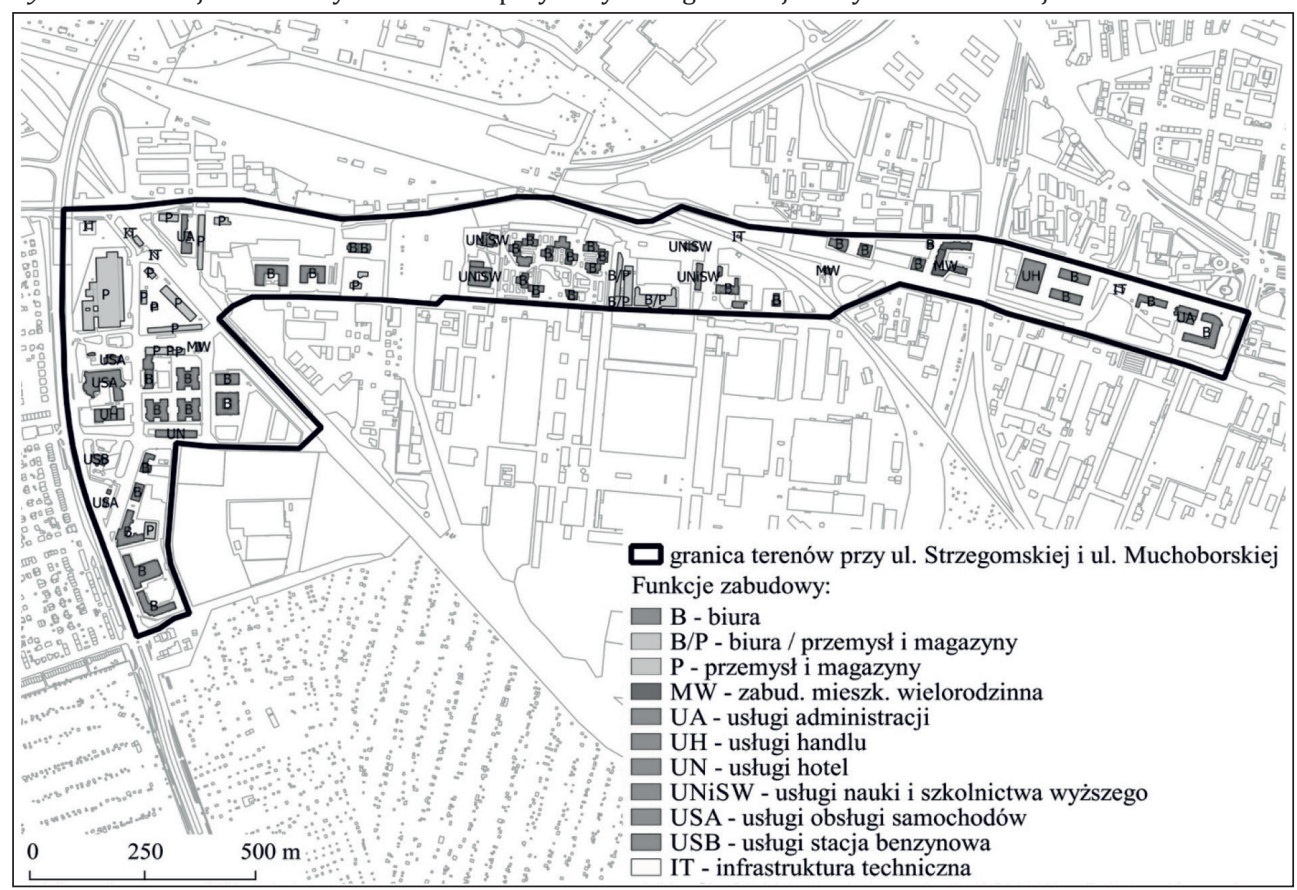

Źródło: opracowanie własne

Sprawdzono również, jaka jest proporcja pomiędzy zabudową inną niż biurowa w stosunku do istniejącej zabudowy biurowej. Na $100 \mathrm{~m}^{2}$ powierzchni biurowej przypada $14 \mathrm{~m}^{2}$ zabudowy usługowej (z wyłączeniem biur) oraz $16 \mathrm{~m}^{2}$ przemysłowej i magazynowej. Taka proporcja wskazuje na fakt, że biura nie dominują na danym obszarze. Ciągle występują inne formy zagospodarowania przestrzeni, które ją urozmaicają. Czy zostaną również zmienione na budynki biurowe, zależy od koniunktury gospodarczej i decyzji planistycznych władz Wrocławia.

\section{WNIOSKI}

Analizowane tereny wzdłuż ulicy Strzegomskiej i ulicy Muchoborskiej we Wrocławiu są interesującym przykładem dynamicznych zmian przestrzennych, jakie można obserwować na przestrzeni około 200 lat, co w kontekście procesów urbanistycznych nie jest długim okresem czasu. Zachodzące przemiany wynikają z rozwoju technologicznego i uwarunkowań gospodarczych. W wyniku procesu industrializacji i rozwoju przemysłu na terenach przy ulicy Strzegomskiej pod koniec XIX wieku powstały pierwsze duże zakłady przemysłowe. Nie był to wtedy jeszcze obszar należący do miasta Wrocławia. Wiodąca funkcja przemysłowa była utrzymywana także w powojennych planach zagospodarowania Wrocławia. Kolejny przełom nastąpił w latach 90. XX wieku, kiedy uwarunkowania do lokalizowania dużych zakładów przemysłowych zmieniły się i znacząco wzrosło zapotrzebowanie na powierzchnie biurowe. W dokumentach planistycznych obszar ten został przeznaczony na aktywności gospodarcze i usługi. Oba przeznaczenia terenu umożliwiają powstawanie zabudowy biurowej. Konsekwentnie od początku XXI 
wieku powstaje w tej części Wrocławia największa koncentracja budynków biurowych w mieście, głównie wzdłuż ulicy Strzegomskiej i ulicy Muchoborskiej. Nowe inwestycje biurowe są lokalizowane na jeszcze niezabudowanych działkach lub w wyniku przekształceń dotychczasowego zagospodarowania terenu, głównie zabudowy magazynowej i przemysłowej. Dynamikę zmian w zagospodarowaniu badanego obszaru można zauważyć porównując go do terenów przyległych. Dominuje tam zabudowa z okresów poprzedzających powstanie analizowanej dzielnicy biurowej. Na terenach przyległych nie jest zauważalna tak duża wymiana zabudowy na nową jak na terenie koncentracji budynków biurowych przy ulicy Strzegomskiej i ulicy Muchoborskiej.

Struktura funkcjonalna badanej części Wrocławia pokazuje, że jest to miejsce tworzące znaczące skupisko miejsc pracy w mieście. Ponad 70\% powierzchni całkowitej zabudowy to budynki biurowe. Kolejną największą grupą jest przemysł i magazyny. Podobny procent stanowią usługi szkolnictwa wyższego. Zatem strukturę tej dzielnicy biznesowej nie stanowią wyłącznie biura. Około 30\% to inne formy zagospodarowania terenu. Jednak charakter dzielnicy biurowej jest bardzo wyraźny. Uwidacznia się na tle analizy funkcjonalnej terenów przyległych, których funkcja jest głównie związana z miejscem zamieszkania. Jednak odsetek innych form zagospodarowania terenów jest ciągle wysoki, co wynika z bliskości centrum miasta. Takie zróżnicowanie nie występuje na obszarze badanej dzielnicy biurowej.

Pod względem funkcjonalnym i przestrzennym, badana koncentracja wyróżnia się ze swojego otoczenia. Na północy i zachodzie graniczy głównie z terenami mieszkaniowymi, a od południowej i wschodniej strony z terenami aktywności gospodarczej oraz ogródkami działkowymi. Poczucie odrębności od najbliższego sąsiedztwa generują liczne linie kolejowe, które niegdyś zdecydowały o dużej atrakcyjności i rozwoju tej części Wrocławia. Aktualnie oddzielają badany teren od jego sąsiedztwa oraz dzielą go wewnętrznie, tworząc znaczące bariery urbanistyczne. Jednak charakterystyczna oś zabudowy biurowej, która rozpoczyna się na placu Strzegomskim a kończy przy ulicy Muchoborskiej, jest bardzo wyraźna. Kształtuje się tutaj dzielnica biznesowa raczej o liniowym charakterze.

Przekształcenie terenów poprzemysłowych na inne aktywności jest powszechnym zjawiskiem na obszarze Wrocławia. Proces ten rozpoczął się po 1989 roku i objął aż 60\% terenów poprzemysłowych (Sikorski, 2012). Początkowo były one przekształcane na aktywności gospodarcze, typu: firmy handlowe, auto-myjnie, warsztaty samochodowe, firmy budowlane oraz magazynowo-transportowe (Sikorski, 2012). Tworzenie dzielnicy biurowej jest charakterystyczne dla tej części Wrocławia przy ulicy Strzegomskiej i ulicy Muchoborskiej. Jednak zjawisko przekształcania terenów poprzemysłowych na koncentracje budynków biurowych nie jest nowe. Występuje również w innych polskich miastach, a najbardziej znanym przykładem jest Służewiec Przemysłowy w Warszawie. Jego geneza powstawania jest analogiczna do wrocławskiej dzielnicy biurowej. Od lat 90. XX wieku Służewiec Przemysłowy stopniowo był przekształcany z dzielnicy przemysłowej w biurową (Kierzkowska, 2017). Tutaj również dominuje zabudowa biurowa, która stanowi 79,8\%. Pozostałe rodzaje zagospodarowania terenów to przemysł i magazyny (13\%), usługi $(4,9 \%)$ i zabudowa mieszkaniowa $(1,4 \%)$ (Kierzkowska, 2017). Jednym z największych przekształceń terenów poprzemysłowych w Europie jest Canary Wharf. Londyńskie doki od lat 80. XX wieku stopniowo zamieniano w biura. Jest to struktura przestrzenna, która składa się prawie wyłącznie z biur - 95,4\% (Kierzkowska, 2017). Zatem powstanie wrocławskiej koncentracji budynków biurowych na 
terenach poprzemysłowych nie jest nowym zjawiskiem. Takie inwestycje występują w innych europejskich miastach. Różnią się od siebie głównie uwarunkowaniami wewnętrznymi oraz polityką przestrzenną, jaką realizuje miasto tworząc nowe miejsca pracy.

\section{REKOMENDACJE}

Zmiany jakie nastąpiły na terenach wzdłuż ulic Strzegomskiej i Muchoborskiej we Wrocławiu pokazują jak dynamicznie może zmieniać się zagospodarowanie terenu tworzące miejsce pracy. Takie przeznaczenie terenu dostosowuje się do zmian gospodarczych i przyjmuje taką funkcję zabudowy, na jaką aktualnie jest zapotrzebowanie. Jest to stosunkowo łatwa i szybka do przekształcenia aktywność, co pozwala na dostosowanie do zmieniających się trendów. Nie jest to możliwe w przypadku wielu innych form zagospodarowania terenu, na przykład zabudowy mieszkaniowej, której zmiana na inne przeznaczenie jest obarczona czynnikiem społecznym. Zatem rewitalizacja terenów poprzemysłowych, które nie spełniają już swojej funkcji, poprzez budowę budynków biurowych jest stosunkowo łatwa. Jest to też metoda na utrzymanie miejsc pracy na obszarze miasta. Podczas krótkiego procesu inwestycyjnego można uzyskać wiele korzyści społecznych i ekonomicznych, jak również zrewitalizować daną część miasta (Hall, Tewdwr-Jones, 2011).

Należy zaznaczyć, że powstawanie dużych skupisk zabudowy biurowej może generować również negatywne skutki. Do najważniejszych zalicza się znaczące problemy komunikacyjne. Tak duża koncentracja miejsc pracy wymaga dobrego skomunikowania w skali całego miasta, głównie transportem zbiorowym. Kolejnym zagadnieniem jest niskiej jakości przestrzeń publiczna między budynkami biurowymi, połączona z wysoką intensywnością zabudowy. Problem złej jakości przestrzeni publicznej na badanym obszarze został wymieniony w Studium uwarunkowań i kierunków zagospodarowania przestrzennego Wrocławia z 2018 roku. Zwrócono uwagę na konieczność inwestycji mających podnieść jakość przestrzeni pomiędzy budynkami. Chyba jednym z najczęściej wymienianych problemów jest też monofunkcyjność takich dzielnic biznesowych (Marcuse, 2008; Majoor 2009). Tworzą one dość jednolite struktury przestrzenne, pozbawione użytkowników poza godzinami pracy w biurach. Alternatywą może być rozpraszanie miejsc pracy na obszarze całego miasta i tworzenie mniejszych skupisk obiektów biurowych. Jednak nie zawsze takie działania planistyczne są możliwe, a proponowane lokalizacje wybierane przez inwestorów. Atutem wrocławskiej koncentracji budynków biurowych jest fakt, że jest ona ciągle na etapie powstawania. Zatem zadbanie o różnorodność funkcjonalną tego obszaru i wysoką jakość przestrzeni jest ciągle możliwe.

\section{Literatura \\ References}

Aranya, R. (2003). Globalisation and urban restructuring of Bangalore, India. Growth of the IT industry, its spatial dynamics and local planning responses. Trondheim: Norwegian University of Technology, Doctoral theses at NTNU.

Barski, J., Zathey, M.W. (2018) Industrial heritage and post-industrial situation in the post-transformation era in Lower Silesia (Poland). GeoScape, 12(1), 17-25. 
Chmielewski, J.M., Kotaszewicz, T., Mieszkowski, W. (2004). Atlas Historyczny Warszawy, Plany Zagospodarowania Przestrzennego w latach 1916-2002. Warszawa: Stowarzyszenie Przyjaciół Archiwum Państwowego m. st. Warszawy.

Derudder, B., Witlox, F. (2008). What's is a 'world class' city? Comparing conceptual specifications of cities in the context of a global network. W: M. Jenkes, D. Kozak, P. Takkanon, (red.), World cities and urban form. Fragmented, polycentric, sustainable? Londyn: Routledge, 11-23.

Friedmann, J. (2006). The World City Hypothesis. W: N. Brenner, R. Keil (red.), The Global Cities Reader. London: Routledge, 67-72.

Hall, P.G. (1997). Megacities, world cities and global cities. Amsterdam: Stichting Megacities (Megacities Lecture, 1). Pozyskano z http://megacities.nl/?page_id=284 (dostęp 12.11.2014).

Hall, P.G., Tewdwr-Jones, M. (2011). Urban and regional planning. Londyn: Routledge.

Hall, P.G. (2014). Good cities, better lives. How Europe discovered the lost art of urbanism. Abingdon, Oxon: Routledge.

Kazimierczak, J., Kosmowski, P. (2018). Post-industrial urban areas in the context of ruination, demolition and urban regeneration in a post-socialist city. Experiences of Łódź, Poland. Finisterra, 109, 35-51.

Ketels, C.H.M. (2011). Clusters and competitiveness. Porter's contribution. W: R. Huggins, H. Izushi (red.), Competition, Competitive Advantage, and Clusters. The ideas of Micheal Porter. Oxford: University Press, 173-192.

Kierzkowska, A. (2017). The style as a factor of office building concentration locations in European cities. Civil and Environmental Engineering Reports, 24(1), 5-20.

Majoor, S.J.H. (2009). The disconnected innovation of new urbanity in Zuidas Amsterdam, Ørestad Copenhagen and Forum Barcelona. European Planning Studies, 9, 1379-1403.

Maleczyński K., Morelowski, M., Ptaszycka, A. (1956). Wrocław. Rozwój urbanistyczny. Warszawa: Budownictwo i Architektura.

Marcuse, P. (2008). Globalisation and the forms of cities. W: M. Jenks, D. Kozak, P. Takkanon (red.), World cities and urban form. Fragmented, polycentric, sustainable? Londyn: Routledge, 2540.

Miejscowy plan zagospodarowania przestrzennego dla części zespołu urbanistycznego Grabiszyn Północny Przemysłowy we Wrocławiu. (2007a). Uchwała NR X/210/07 Rady Miejskiej Wrocławia z dnia 14 czerwca 2007 r. Pozyskano z http://uchwaly.um.wroc.pl/uchwala. aspx?numer=X/210/07 (dostęp 02.10.2013).

Miejscowy plan zagospodarowania przestrzennego obszaru rozwoju Wzgórze Mikołajskie we Wrocławiu. (2007b). Uchwała NR XI/232/07 Rady Miejskiej Wrocławia z dnia 5 lipca 2007 r. Pozyskano z http://uchwaly.um.wroc.pl/uchwala.aspx?numer=XI/232/07 (dostęp 02.10.2013).

Miejscowy plan zagospodarowania przestrzennego terenu ograniczonego ulicami Szwajcarska, Klecińskq, Muchoborska, Duńskq i liniq kolejowq we Wrocławiu. (2002). Uchwała $\mathrm{Nr}$ L/1758/02 Rady Miejskiej Wrocławia z 4 lipca 2002 r. Pozyskano z http://uchwaly. um.wroc.pl/uchwala.aspx?numer=L/1758/02 (dostęp 02.10.2013).

Miejscowy plan zagospodarowania przestrzennego w rejonie Muchoboru Małego Komercyjnego we Wrocławiu. (2007c). Uchwała NR VIII/162/07 Rady Miejskiej Wrocławia z 19 kwietnia 2007 r. Pozyskano z http://uchwaly.um.wroc.pl/uchwala.aspx?numer=VIII/162/07 (dostęp 02.10.2013).

Miejscowy plan zagospodarowania przestrzennego w rejonie ulicy Duńskiej we Wrocławiu. (2008). Uchwała NR XXVI/943/08 Rady Miejskiej Wrocławia z 6 listopada 2008 r. Pozyskano z http://uchwaly.um.wroc.pl/uchwala.aspx?numer=XXVI/943/08 (dostęp 02.10.2013).

Okólska, H., Sobociński, W., Szykuła, K., Wytyczak, R. (1999). Wrocław na planach. XVI-XX wiek. Wrocław: Muzeum Historyczne.

Porter, M. (1998). On Competition. Boston: Harvard Business School Publishing.

Przyłęcka, D. (2006). Odbudowa i rozwój Wrocławia w planach zagospodarowania przestrzennego $z$ lat 1945-1994. Wrocław: Agencja Wydawniczo-Poligraficzna Rubikon.

Sassen, S. (2001). The Global City, New York, London, Tokyo. Princeton: Princeton University Press.

Sassen, S. (2006a). Cities and communities in the global economy. W: N. Brenner, R. Keil (red.), The Global Cities Reader. Londyn; Nowy Jork: Routledge, 82-88. 
Sassen, S. (2006b). Cities in a world economy. Thousand Oaks: Pine Forge Press.

Sikorski, D. (2012). Zmiany funkcjonalne terenów przemysłowych i poprzemysłowych we Wrocławiu po 1989 roku. W: B. Namyślak, R. Szmytkie (red.), Przekształcenia przestrzeni miejskiej Wrocławia. Ujęcie geograficzne. Wrocław: Uniwersytet Wrocławski, 33-54.

Sitek S., Szajnowska-Wysocka, A. (2018). Proces rewitalizacji obszarów poprzemysłowych i jego wpływ na krajobraz miejski. Prace Komisji Krajobrazu Kulturowego, 40(2), 225-242.

Studium uwarunkowań i kierunków zagospodarowania przestrzennego Wrocławia. (2010). Uchwała Nr L/1467/10 Rady Miejskiej Wrocławia z 20 maja 2010 r. Pozyskano z http:// uchwaly.um.wroc.pl/uchwala.aspx?numer=L/1467/10 (dostęp 02.10.2013).

Studium uwarunkowań i kierunków zagospodarowania przestrzennego Wrocławia. (2018). Uchwała Nr L/1177/18 Rady Miejskiej Wrocławia z dnia 11 stycznia 2018 r. Pozyskano z http://uchwaly.um.wroc.pl/uchwala.aspx?numer=L/1177/18 (dostęp 01.12.2019).

Swyngedouw E., Moulaert F., Rodriguez, A. (2002). Neoliberal Urbanization in Europe: LargeScale Urban Development Projects and the New Urban Policy. Antipode, 34(3), 542-577.

System Informacji Przestrzennej Wrocławia. (2014, październik). Pozyskano z https://geoportal.wroclaw.pl/

Anna Kierzkowska, dr inż., Politechnika Wrocławska, Wydział Architektury, Katedra Urbanistyki i Procesów Osadniczych. Dr inż. Anna Kierzkowska ukończyła planowanie przestrzenne na Wydziale Architektury Politechniki Wrocławskiej. Na tej samej uczelni podjęła studia doktoranckie, które zakończyła zdobyciem z wyróżnieniem tytułu doktora. Jej praca badawcza dotyczyła „Koncentracji budynków biurowych w europejskich miastach". Podczas studiów doktoranckich odbyła staże naukowe na uczelniach w Trondheim (Norwegia), Bolonii (Włochy) i Warszawie. Wzięła udział w licznych szkoleniach i konferencjach naukowych. Dr inż. Anna Kierzkowska posiada doświadczenie w pracy zawodowej w polskich i zagranicznych biurach projektowych. Jest współautorką opracowań planistycznych na poziome regionalnym i lokalnym.

Anna Kierzkowska, PhD Eng., Wroclaw University of Science and Technology, Faculty of Architecture, Chair of Town Planning and Settlement Processes. Anna Kierzkowska has graduated from spatial planning at the Wroclaw University of Technology, Faculty of Architecture. Subsequently, she successfully finished her PhD studies at the same university. Her PhD thesis concerned 'Office building concentrations in European cities'. During her PhD studies, she had internships at universities in Trondheim (Norway), Bologna (Italy) and Warsaw (Poland). She also participated in many national and international conferences and trainings. Anna Kierzkowska has experience as a designer in various urban offices. She is a co-author of urban projects on a local and regional level.

ORCID: https://orcid.org/ 0000-0003-2158-5311

\section{Adres/address:}

Politechnika Wrocławska

Wydział Architektury

Katedra Urbanistyki i Procesów Osadniczych

ul. Prusa 53/55

50-317, Wrocław, Polska

e-mail: anna.kierzkowska@pwr.edu.pl 